\title{
Reprocessing of Single-Use Medical Devices: Clinical and Financial Results
}

\author{
Bruno de Sousa Martins ${ }^{a}$ João Queiroz e Melo ${ }^{b}$ João Logarinho Monteiro ${ }^{c}$ \\ Graça Rente $^{d}$ Pedro Teixeira Bastos ${ }^{d}$ \\ aEscola de Saúde do Porto, Associação de Politécnicos do Norte, Porto, Portugal; b Ecotlon - Economia na Saúde, \\ Lisboa, Portugal; ' Associação Portuguesa de Administradores Hospitalares, Lisboa, Portugal; ${ }^{d}$ Hospital de São João, \\ Centro Hospitalar de São João, Porto, Portugal
}

\section{Keywords}

Certified reprocessing $\cdot$ Device reuse $\cdot$ Single-use medical device $\cdot$ Clinical efficiency $\cdot$ Cost reduction

\begin{abstract}
Introduction: Excellent results regarding clinical efficacy and cost reduction are achieved by using certified reprocessed single-use medical devices (SUMDs). This explains why this practice is common in most hospitals across the USA and Germany. However, this is not a common practice at a national level and there are no reports regarding its use in Portugal. We present our experience using these methods at Centro Hospitalar de São João (CHSJ) in Porto. Objective: The aim of this study was to compare the clinical results and the financial impact of the use of 2 SUMDs, original and reprocessed, namely the linear suture machine GIA Covidien ${ }^{\mathrm{TM}}$ and Harmonic ACE ${ }^{\circledR}$ scissors. Method: A group of 733 patients operated in 2014 was evaluated. Of these patients, 316 were operated on with reprocessed SUMDs and 417 with original SUMDs. Variables referring to the clinical and financial results were analyzed through clinical and management information provided by Unidade de Gestão Autónoma de Cirurgia. A comparison between groups was performed using the $X^{2}$ test and the Mann-Whitney test. Results: Indica-
\end{abstract}

tors related to clinical efficacy show that the use of these SUMDs, professionally reprocessed, did not represent any added risk in comparison to the use of original devices. Regarding costs, there is a very significant difference between the use of a new medical device and that of a reprocessed one. In the case of the Harmonic $A C E^{\circledR}$ scissors and of the linear suture machine GIA Covidien ${ }^{\mathrm{TM}}$, savings were up to 50\% per device. Conclusion: This study, the first in Portugal, confirms the economic advantages of reprocessing these 2 devices. The financial benefit was obtained with maintenance of the same clinical results as the ones achieved using original devices. These results are in line with the published literature, proving the validity of using SUMDs after professionally certified reprocessing.

(C) 2019 The Author(s). Published by S. Karger AG, Basel on behalf of Escola Nacional de Saúde Pública

\section{Reprocessamento de Dispositivos Médicos de Uso Único: Resultados Clínicos e Financeiros}

Palavras Chave

Reprocessamento certificado · Reutilização - Dispositivo médico de uso único - Eficiência clínica · Redução de custos

\section{KARGER}

E-Mail karger@karger.com www.karger.com/pjp

Karger Open access (c) 2019 The Author(s). Published by S. Karger AG, Basel on behalf of Escola Nacional de Saúde Pública

This article is licensed under the Creative Commons AttributionNonCommercial-NoDerivatives 4.0 International License (CC BYNC-ND) (http://www.karger.com/Services/OpenAccessLicense) Usage and distribution for commercial purposes as well as any distribution of modified material requires written permission.
Bruno de Sousa Martins Rua da Feiteira No. 171 PT-4635-505 Marco de Canaveses (Portugal)

E-Mail desousamartins18@gmail.com 


\section{Resumo}

Introdução: Os excelentes resultados da eficácia clínica e da redução de custos, obtidos com o reprocessamento certificado dos Dispositivos Médicos de Uso Único (DMUU) justificam que seja prática corrente na maior parte dos hospitais, nos Estados Unidos da América e na Alemanha. No entanto, a nível Nacional ainda não é prática comum, não existindo bibliografia sobre a experiência nacional. Apresentamos os resultados obtidos com esta prática no Centro Hospitalar de São João (CHSJ), Porto. Objetivo: Comparar os resultados clínicos e o impacto financeiro da reutilização de dispositivos médicos de uso único, reprocessados profissionalmente. Foram utilizados dois dispositivos de "uso único," a máquina de sutura linear GIA Covidien ${ }^{\mathrm{TM}}$ e a tesoura Harmonic ACE $^{\circledR}$. Método: Analisamos um grupo de 733 doentes operados em 2014 que inclui todos os doentes operados no referido período e em que foram utilizados estes dispositivos. Destes doentes 316 foram operados com DMUU reprocessados, e 417 com DMUU originais. As variáveis referentes aos resultados clínicos e financeiros foram analisadas através dos respetivos registos clínicos e da informação de gestão fornecida pela Unidade de Gestão Autónoma de Cirurgia. A comparação entre grupos foi realizada pela aplicação dos testes de Qui-quadrado e Mann-Whitney. Resultados: Os indicadores relativos à eficácia clínica, comprovaram que o uso destes DMUU reprocessados profissionalmente utilizados nas intervenções cirúrgicas não representou qualquer risco acrescido em comparação com os dispositivos originais. Em termos financeiros, há uma diferença muito significativa entre a aquisição de um dispositivo médico novo ou reprocessado. A diferença no caso da tesoura Harmonic $A C E^{\circledR}$ e na máquina de sutura linear GIA Covidien ${ }^{\mathrm{TM}}$ acarretou poupanças cerca de 50\%. Conclusão: Este primeiro estudo, realizado em Portugal, confirma as vantagens económicas do reprocessamento destes dois dispositivos. O benefício financeiro foi obtido com manutenção da mesma qualidade clínica que se obteve com os dispositivos originais. Os resultados obtidos estão em conformidade com os publicados na literatura, o que confirma que a utilização de alguns dispositivos médicos de uso único após reprocessamento profissional é um método eficiente.

(c) 2019 The Author(s). Published by S. Karger AG, Basel on behalf of Escola Nacional de Saúde Pública

\section{Introduction}

For many years, health-care units have been facing significant challenges regarding the ideal management of financial resources. New sustainability solutions cannot put at risk the safety of the patients, allowing professionals the use of appropriate resources to provide proper care. Within these boundaries, the use of certified professionally reprocessed single-use medical devices (SUMDs) is considered $[1,2]$.

In Portugal, SUMDs are defined according to the law decree number 145/2009 from the 17th of June (article 3, item $r$ ) as "(...) a device used for a single time on a single patient" [3]. Reprocessing is a certified procedure that allows that some SUMDs can be used again after their first usage. European and national legislation [4-6] support this approach. This approach implies rigorous cleaning procedures, disinfection, and sterilization, as well as tests and the restoration of technical and functional safety of the used device $[7,8]$.

This practice was initiated in the USA around 20 years ago and in the last 15 years in Germany [1]. The excellent results regarding cost reduction and clinical efficiency promote it as an example of good clinical practice and reinforce that some SUMDs, after adequate professional handling, may be used again, especially in the areas of cardiology and electrophysiology, ophthalmology, endoscopy, and laparoscopy [8].

Since 2012, Centro Hospitalar de São João (CHSJ) has been using 2 reprocessed SUMDs (linear suture machine GIA Covidien ${ }^{\mathrm{TM}}$ and the Harmonic ACE ${ }^{\circledR}$ scissors), reprocessed by a certified reprocessor duly accredited [9]. Two studies evaluated the safety and performance of reprocessed Harmonic $\mathrm{ACE}^{\circledR}$ scissors as compared to new ones. In the first study, scenarios were developed in which the reprocessed device was subject to contamination (storage, transportation, and cleaning) followed by a 2 -year accelerated aging process. No signs of visible contamination were detected, with insignificant levels of protein and hemoglobin [10]. In the second study, performance was compared assessing in vivo dissection characteristics and postcut shaft temperatures in Harmonic $\mathrm{ACE}^{\circledR}$ scissors and its counterpart [11]. In both studies, it was verified that the performance and safety of reprocessed Harmonic $\mathrm{ACE}^{\circledR}$ scissors are equivalent to the original $[10,11]$.

The objective of our study was to evaluate the clinical and financial consequences of the use of certified reprocessed SUMDs. 
Table 1. Procedures performed by DRGs

\begin{tabular}{|c|c|c|c|c|}
\hline \multicolumn{2}{|c|}{ DRGs } & \multirow{2}{*}{$\begin{array}{l}\text { R } \\
42\end{array}$} & \multirow{2}{*}{$\begin{array}{r}\text { NR } \\
55\end{array}$} & \multirow{2}{*}{$\frac{\text { Total }}{97}$} \\
\hline 148 & Major procedures in the small intestine and/or large intestine, with CC & & & \\
\hline 154 & Procedures in the esophagus, stomach, and/or duodenum, age $>17$ years, with CC & 30 & 39 & 69 \\
\hline 155 & Procedures in the esophagus, stomach, and/or duodenum, age $>17$ years, without CC & 29 & 40 & 69 \\
\hline 293 & Other procedures, by endocrine, nutritional, and/or metabolic diseases, in OR, without CC & 40 & 34 & 74 \\
\hline 359 & $\begin{array}{l}\text { Procedures in the uterus and/or its attachments for carcinoma in situ and/or nonmalignant disease, } \\
\text { without CC }\end{array}$ & 19 & 40 & 59 \\
\hline 585 & $\begin{array}{l}\text { Major procedures in the stomach, esophagus, duodenum, small intestine, and/or large intestine, with } \\
\text { CC }\end{array}$ & 40 & 68 & 108 \\
\hline
\end{tabular}

R, reprocessed; NR, nonreprocessed; DRG, diagnosis-related group; CC, complications; OR, operating room.

\section{Materials and Methods}

Information was provided by the Unidade Autónoma de Gestão de Cirurgia do CHSJ. Data collection was done using the management reports from the CHSJ in 2014 and the grouping of encrypted diagnosis-related groups (DRGs).

We selected all surgical interventions performed in 2014 in which Harmonic ACE ${ }^{\circledR}$ scissors curves $(5 \mathrm{~mm} / 36 \mathrm{~cm} \mathrm{C} / \mathrm{rod})$ and the linear suture machine GIA Covidien ${ }^{\mathrm{TM}}$ with cut and anastomosis (No. 55/60-3.8, No. 75/80-3.8, and No. 75/80-4.8) were used, either original or reprocessed devices. The hospital selected these 2 devices due to original cost and/or large consumption number.

The populations under study are described using their demographic characteristics. Clinical efficacy is described by data on duration of surgical intervention, postoperative infection incidence, antibiotic consumption (using the daily dose defined [DDD]), reoperations, length of hospital stay, in-hospital mortality, and re-hospitalization rate (complications 30 days after surgical intervention). Cost analysis was based on the cost difference between the acquisition of unique SUMDs as compared to the costs of these SUMDs professionally reprocessed.

\section{Statistical Analysis}

A comparison between the groups regarding clinical effectiveness was performed using the $\chi^{2}$ test to verify if there were significant differences between categorical variables. The Mann-Whitney test was used to analyze the significant differences between numerical variables. A $p$ value of $<0.05$ was considered statistically significant. For the cost analysis, the comparison between groups was based on the cost of purchasing SUMDs from the manufacturer compared to the costs of the reprocessing of the same SUMDs. Acquisition of refills for the linear suture machine GIA Covidien $^{\mathrm{TM}}$ was also considered in the analysis.
Table 2. Demographic characteristics

\begin{tabular}{lccc}
\hline & $\mathrm{R}(n=316)$ & $\mathrm{NR}(n=417)$ & $p$ \\
\hline Mean age \pm SD, years & $56.7 \pm 17.3$ & $56.6 \pm 16.7$ & 0.996 \\
Male, $n(\%)$ & $132(41.8)$ & $166(39.8)$ & 0.592 \\
Female, $n(\%)$ & $184(58.2)$ & $251(60.2)$ & 0.592 \\
\hline
\end{tabular}

$R$, reprocessed; NR, nonreprocessed.

\section{Sample}

Surgical interventions were identified for each DRG in which SUMDs were used, regardless of those devices being original or reprocessed. Two groups were defined. Patients either operated on with original medical devices (nonreprocessed [NR] group) or with reprocessed medical devices (R group). A total of 733 surgical interventions were analyzed, during which 316 patients were treated with reprocessed SUMDs and 417 with nonreprocessed SUMDs.

The DRGs, referring to the surgical interventions analyzed, are shown in Table 1.

\section{Results}

\section{Clinical Outcomes}

The mean age in the $R$ group was $56.7 \pm 17.3$ years and in the NR group $56.6 \pm 16.7$ years. In both groups, females were predominant (Table 2). 
Table 3. Clinical outcomes

\begin{tabular}{|c|c|c|c|c|c|c|c|c|c|c|c|}
\hline DRG & SUMD & $\mathrm{DDD} \pm \mathrm{SD}$ & $p$ & days $\pm \mathrm{SD}$ & $p$ & hours \pm SD & $p$ & $n(\%)$ & $p$ & $n(\%)$ & $p$ \\
\hline \multirow[t]{2}{*}{75} & NR & $6.13 \pm 14.04$ & 0.313 & $7.61 \pm 4.81$ & 0.663 & $1.53 \pm 0.75$ & 0.667 & $2(8.70)$ & 0.581 & 0 & 0.000 \\
\hline & $\mathrm{R}$ & $2.4 \pm 2.48$ & & $6.72 \pm 2.93$ & & $1.59 \pm 0.72$ & & $2(5.13)$ & & 0 & \\
\hline 148 & NR & $3.21 \pm 5.53$ & 0.113 & $11.4 \pm 9.78$ & 0.083 & $2.28 \pm 1.21$ & 0.664 & $6(10.90)$ & 0.258 & 0 & 0.044 \\
\hline \multirow[t]{2}{*}{149} & NR & $7.21 \pm 14.5$ & 0.852 & $8.67 \pm 6.32$ & 0.564 & $2.09 \pm 1.00$ & 0.599 & $3(6.81)$ & 0.613 & 0 & 0.000 \\
\hline & $\mathrm{R}$ & $3.9 \pm 5.51$ & & $10.52 \pm 9.04$ & & $2.31 \pm 172$ & & $2(9.54)$ & & 0 & \\
\hline \multirow[t]{2}{*}{154} & NR & $3.29 \pm 8.04$ & 0.193 & $11.41 \pm 10.25$ & 0.079 & $3.52 \pm 1.68$ & 0.348 & $5(12.82)$ & 0.419 & 0 & 0.000 \\
\hline & $\mathrm{R}$ & $3.55 \pm 5.72$ & & $12.2 \pm 7.26$ & & $3.39 \pm 2.11$ & & $6(20.00)$ & & 0 & \\
\hline 155 & NR & $9.91 \pm 28.42$ & 0.75 & $8.53 \pm 12.07$ & 0.694 & $2.07 \pm 1.19$ & 0.298 & $5(12.50)$ & 0.783 & 0 & 0.000 \\
\hline \multirow[t]{2}{*}{293} & NR & $5.86 \pm 8.44$ & 0.166 & $9.32 \pm 11.35$ & 0.038 & $1.11 \pm 0.53$ & 0.507 & 0 & 0.000 & 0 & 0.000 \\
\hline & $\mathrm{R}$ & $2.94 \pm 7.37$ & & $5.73 \pm 0.78$ & & $1.06 \pm 0.51$ & & 0 & & 0 & \\
\hline \multirow[t]{2}{*}{359} & NR & $7.72 \pm 26.64$ & 0.714 & $6.93 \pm 13.68$ & 0.022 & $2.12 \pm 0.75$ & 0.764 & 0 & 0.000 & 0 & 0.000 \\
\hline & $\mathrm{R}$ & $4.99 \pm 7.06$ & & $2.84 \pm 0.6$ & & $2.04 \pm 1.12$ & & 0 & & 0 & \\
\hline \multirow[t]{2}{*}{585} & NR & $4.4 \pm 7.19$ & 0.129 & $16.44 \pm 15.48$ & 0.058 & $3.37 \pm 2.20$ & 0.904 & $10(14.70)$ & 0.967 & $12(17.64)$ & 0.141 \\
\hline & $\mathrm{R}$ & $7.35 \pm 12.07$ & & $19.7 \pm 14.14$ & & $3.34 \pm 2.06$ & & $6(15.00)$ & & $3(7.50)$ & \\
\hline \multirow[t]{2}{*}{ All DRGs } & NR & $5.61 \pm 15.21$ & 0.319 & $10.36 \pm 12.00$ & 0.881 & $2.45 \pm 1.52$ & 0.161 & $33(7.91)$ & 0.678 & $12(2.88)$ & 0.396 \\
\hline & $\mathrm{R}$ & $4.10 \pm 7.63$ & & $9.55 \pm 8.92$ & & $2.33 \pm 1.53$ & & $28(8.86)$ & & $6(1.90)$ & \\
\hline
\end{tabular}

DRG, diagnosis-related groups; SUMD, single-use medical device; R, reprocessed; NR, nonreprocessed; SD, standard deviation; DDD, defined daily dose.

The postoperative infection rate was on average $12.9 \%$, being $12.3 \%$ for the R group and $13.4 \%$ for the NR group. There was a wide range of differences in the rate of postoperative infections in each DRG group, depending on the type of surgery and the severity of the preoperative condition. Still, there were no differences between the 2 groups $(p=0.664)$.

Table 3 describes the consumption of antibiotics (as DDD), length of hospital stay, time of surgery, readmission rate, and in-hospital mortality. A comparison of the consumption of antibiotics (DDD) between the R and NR groups and for all DRG subgroups showed no significant differences $(p=0.319)$.

The duration of the surgical intervention was on average $2 \mathrm{~h}$ and $23 \mathrm{~min}(p=0.161)$, and length of hospital stay was approximately 10 days in both groups $(p=0.881)$. Rehospitalization was required for 28 patients in the $\mathrm{R}$ group and for 33 patients in the NR group $(p=0.678)$.
Table 4. Cost difference between cases

\begin{tabular}{|c|c|c|c|}
\hline List of medical devices & $\mathrm{R}$ & NR & Savings \\
\hline \multicolumn{4}{|c|}{ Harmonic $A C E^{\circledR}$ scissors } \\
\hline $5 \mathrm{~mm} / 36 \mathrm{~cm} \mathrm{C} /$ Haste & $\begin{array}{l}246.00 \\
\text { EUR }\end{array}$ & $\begin{array}{l}512.43 \\
\text { EUR }\end{array}$ & $\begin{array}{l}266.43 \text { EUR } \\
(52 \%)\end{array}$ \\
\hline \multicolumn{4}{|c|}{ Linear suture machine with cut and anastomosis GIA Covidien ${ }^{T}$} \\
\hline No. 55/60-3.8 & $\begin{array}{l}58.05 \\
\text { EURa }\end{array}$ & $\begin{array}{l}106.98 \\
\text { EUR }\end{array}$ & $\begin{array}{l}48.93 \text { EUR } \\
(46 \%)\end{array}$ \\
\hline No. $75 / 80-3.8$ & $\begin{array}{l}58.05 \\
\text { EURa }\end{array}$ & $\begin{array}{l}133.82 \\
\text { EUR }\end{array}$ & $\begin{array}{l}75.77 \text { EUR } \\
(57 \%)\end{array}$ \\
\hline No. $75 / 80-4.8$ & $\begin{array}{l}58.05 \\
\text { EURa }\end{array}$ & $\begin{array}{l}140.28 \\
\text { EUR }\end{array}$ & $\begin{array}{l}\text { 82.23 EUR } \\
(59 \%)\end{array}$ \\
\hline
\end{tabular}

$\mathrm{R}$, reprocessed; NR, nonreprocessed. ${ }^{\mathrm{a}}$ Includes the purchase of 2 original staple cartridges. 
Table 5. Total cost with single-use medical devices (Harmonic $A C E^{\circledR}$ scissors and linear suture machine GIA Covidien $^{\mathrm{TM}}$ )

\begin{tabular}{|c|c|c|c|c|}
\hline & \multicolumn{4}{|l|}{2014} \\
\hline & $\begin{array}{l}\text { linear suture machine GIA } \\
\text { Covidien }^{\mathrm{TM}}, n\end{array}$ & expense & $\begin{array}{l}\text { Harmonic } \mathrm{ACE}^{\circledR} \\
\text { scissors, } n\end{array}$ & expense \\
\hline NR & 178 & 23,819.96 EUR & 418 & 214,195.74 EUR \\
\hline $\mathrm{R}$ & 193 + recharge $(386)$ & $11,203.65$ EUR & 285 & 70,110.00 EUR \\
\hline Savings & - & 14,623.61 EUR & - & 75,932.55 EUR \\
\hline
\end{tabular}

$\mathrm{R}$, reprocessed; NR, nonreprocessed.

Hospital mortality in the R group was $1.90 \%$, resulting in 6 deaths, and it was $2.88 \%$ ( 12 deaths) in interventions in which new devices were used (NR group). Mortality was different in patients in DRGs 148 and 585. These interventions were mostly life-saving procedures in extremely sick patients, with 11-36 patients having a secondary diagnosis, including cardiogenic shock and renal failure. The reasons for death were not related to the use of either reprocessed or nonreprocessed devices. There were no reoperations in either groups.

\section{Cost Analysis}

Data in Table 4 show the costs of purchasing new devices as compared to the reprocessing costs of these SUMDs after use. Acquisition costs were obtained by the manufacturer company catalog that supplies the SUMDs to the CHSJ. Values for reprocessing were established between the CHSJ and the reprocessing company by protocol. The reprocessing costs of the devices include the evaluation and validation of the entire 7-step reprocessing cycle, from collection to delivery back to the hospital, with no additional costs.

The acquisition costs of the new Harmonic $\mathrm{ACE}^{\circledR}$ scissors and those of reprocessed ones differed by $52 \%$ per device. In the case of the linear suture machine GIA Covidien $^{\mathrm{TM}}$, the difference was less, due to the need to buy additional original staple cartridges.

Table 5 shows the total of devices used as well as the costs with each of the options for the year 2014. Savings in Table 5 were calculated based on the difference between buying all SUMDs new without reprocessing and purchasing/reprocessing the SUMDs by the CHSJ. A total of 193 linear suturing machines GIA Covidien ${ }^{\mathrm{TM}}$ were reprocessed, saving EUR 14,623.61. These devices use staples that need to be originals and must be purchased separately. In each procedure, an average of 2 new cartridges was used. For this study, the value of EUR 7.5 was used for each recharge, corresponding to an expense of EUR 2,895. Of the Harmonic ACE ${ }^{\circledR}$ scissors, 285 were reprocessed, corresponding to savings of EUR $75,932.55$.

\section{Discussion}

Several authors have documented a cost reduction of around $50 \%$ due to the use of reprocessed SUMDs [1215]. Because of the strict requirements for a correct reprocessing, many hospitals use certified third-party outside bodies to reprocess their devices [16-19]. In addition to the economic advantages, reprocessing is now considered as one of the most efficient measures for hospitals to immediately reduce some of their negative environmental impact $[20,21]$. Approximately 10 million medical devices have been reprocessed in the German market with strict quality standards for reprocessing approved by the national regulatory boards, and there were no complaints concerning this activity [16].

In our study, the groups submitted to surgical intervention with reprocessed and nonreprocessed SUMDs were comparable with respect to their demographic characteristics. The incidence of infection was similar in both groups. We measured this incidence using the postoperative infection rate and an analysis of the consumption of antibiotics, which is a more differentiated method of tracing the eventual occurrence of infectious complications, which would lead to an increase in the consumption of antibiotics. If this had happened, it might have been due to the use of the reprocessed devices [10]. The duration of the surgical intervention and 
the length of hospital stay were similar in both groups, which confirms the scientific evidence found internationally [11].

There were no significant differences between the use of new and reprocessed devices regarding the incidence of rehospitalization and hospital mortality. The analysis by DRG subgroups showed a difference in mortality in DRGs 148 and 585. Out of the 18 patients who died in these 2 groups, 6 were operated on using reprocessed devices and the other 12 using original devices. It has to be emphasized that these DRGs refer to pathologies of the gastrointestinal system in patients who, at the time of surgery, already suffered from established severe complications, such as sepsis, severe bleeding, pulmonary embolism, and shock. The reason for death was not related to the use of the devices in any case. There was no need for reoperations in either group.

As a result, no increased risk was revealed with regard to the use of reprocessed SUMDs compared to the use of original SUMDs, and, therefore, reprocessed SUMDs do not compromise patient safety. Our experience shows that the concerns pronounced by several entities, which point out eventual risks associated with patient safety as an argument for not using reprocessed SUMDs, are not justified, and it confirms published data about the safety of using properly reprocessed SUMDs [16, 17, 22].

With regard to the economic analysis indicators, there is a huge difference between the cost of acquiring a new SUMD and a reprocessed device, and this difference in the case of the Harmonic $\mathrm{ACE}^{\circledR}$ scissors and the linear suture machine GIA Covidien ${ }^{\mathrm{TM}}$ comprises a saving around $50 \%$ per device, confirming the results obtained in international studies $[15,16,23,24]$. This practice allowed for a yearly saving of EUR 90,556.16 just for the 2 devices.

Each medical device analyzed here can be reprocessed up to 2 times, which means that each new medical device purchased can be used 2 more times after professional treatment. To perform a fourth surgery, a new medical device needs to be purchased. A total of 596 new devices were purchased; 478 went through 1 reprocessing cycle, so by the year 2014 the stock of new devices was sufficient.

Our data are consistent with the fact that the certified reprocessing process requires a rigorous inspection, obeying demanding criteria and guidelines specific to each device. These stringent criteria allow the detection of any type of anomaly, which is not the case in original medical devices whose quality control is done by sampling $[19,25,26]$.

Reprocessing of Single-Use Medical Devices
It is important to emphasize that not all SUMDs are reprocessable. Before they are accepted for clinical use, the methods of reprocessing, specific for each device, are validated and approved by the regulatory agencies, as was done with the devices our hospital had chosen to use [19].

Over the years, CHSJ has increased the use of reprocessed SUMDs. If this growth continues, it is expected that the optimum number of uses of these 2 devices can be reached. This approach allows a better use of resources, leading to an improvement in hospital sustainability.

\section{Conclusion}

Our study is the first analysis in Portugal of clinical and financial results obtained for patients undergoing surgical procedures using certified professionally reprocessed SUMDs (Harmonic ACE ${ }^{\circledR}$ scissors and linear suture machine). To assess clinical efficacy, a comparison was made with a similar group of patients undergoing surgical intervention with original devices in the same time period. Clinical results of patients operated on with reprocessed devices were the same as those of patients in which original medical devices were used.

Financially, the economic benefits of reprocessing are evident, contributing to fostering a culture of economic sustainability of hospitals by reducing costs while maintaining quality of care. We conclude that certified reprocessing of SUMDs has proved to be a safe and effective process, leading to better hospital sustainability.

References

1 Popp W, Rasslan O, Unahalekhaka A, Brenner P, Fischnaller E, Fathy M, et al. What is the use? An international look at reuse of singleuse medical devices. Int J Hyg Environ Health. $2010 \mathrm{Jul} ; 213(4): 302-7$.

2 Ko C. Special report: reprocessing in an era of health care reform. New York, NY: DOTmed; 2014 [cited 2018 Mar 21]. Available from: https://www.dotmed.com/news/story/ 22661?p_begin $=1$

3 Decreto-Lei 145/2009. Diário da República. 115. Ia Série. (2009-6-17): 3707-7765. Available from: https://dre.pt/pesquisa/-/ search/494558/details/maximized

4 Ecotlon. Dispositivo médico de uso único: enquadramento Legal. Lisboa: Ecotlon - Economia na Saúde; 2018 [cited 2018 Mar 21]. Available from: http://www.ecotlon.com/pt/ dmuu/enquadramento-legal/ 
5 Diretiva 93/42/CEE. Jornal Oficial das Comunidades Europeias. L 169 (1993-7-12): 1-60.

6 Diretiva 2007/47/CEE. Jornal Oficial da União Europeia. L 247 (2007-11-05): 21-55.

7 Day P. What is the evidence on the safety and effectiveness of the reuse of medical devices labelled as single-use only? Nzhta Tech Brief Series. 2004;3(2):1-53.

8 FDA. Processing/reprocessing medical devices in health care settings: validation methods and labeling. Silver Spring (MA): Food and Drug Administration; 2011.

9 Ethicon. Especialidades e procedimentos: soluções Ethicon para especialidades e procedimentos. São Paulo, SP: Ethicon. Johnson \& Johnson; 2016 [cited 2018 Jul 21]. Available from: https://www.ethicon.com/latam/pt

10 Carungi RS, Simon IS. Safety and performance evaluation of remanufactured Harmonic scalpels. Washington (DC): Association of Medical Device Reprocessors; 2010 [cited 2018 Mar 21]. Available from: http:// ww w . a m d r.org/w p - content/up loads/2010/09/White-Paper-Safety-and-Performance-Eval-of-Remfd-Harmonic-Scalpels.pdf

11 Lester BR, Miller K, Boers A, Harris DC, Gamble WG. Comparison of in vivo clinical performance and shaft temperature and in vitro tissue temperature and transection times between new and reprocessed harmonic scalpels. Surg Laparosc Endosc Percutan Tech. 2010 Oct;20(5):e150-9.
12 Renton D, Denk P, Varban O. Reprocessed single-use devices in laparoscopy: assessment of cost, environmental impact, and patient safety. Surg Endosc. 2018 Oct;32(10):4310-3.

13 Jacobs P, Polisena J, Hailey D, Lafferty S. Economic analysis of reprocessing single-use medical devices: a systematic literature review. Infect Control Hosp Epidemiol. 2008 Apr;29(4):297-301.

14 Garay OU, Elorrio EG, Rodríguez V, Spira C, Augustovski F, Pichon-Riviere A. Single-use devices in Argentina: cost comparison analysis of a "re-use" versus a "single-use" policy for trocars, endocutters, linear cutters, and harmonic scalpels. Value Health Reg Issues. 2017 Dec;14:89-95.

15 Association of Surgeons of Great Britain and Ireland. Consensus statement on cost-effective and sustainable surgery. 2012. Available from: http://www.rcsi.ie/index.jsp?p= $164 \& n=1026 \& a=1990$

16 Bracklo M, Marczak U, Chergui S. Reprocessing cardiology devices: reviewing 15 years of experience in Germany. Eur Cardiol. 2012; $8(2): 82-3$.

17 Dunnigan A, Roberts C, McNamara M, Benson DW Jr, Benditt DG. Success of re-use of cardiac electrode catheters. Am J Cardiol. 1987 Oct;60(10):807-10.

18 Tessarolo F, Disertori M, Caola I, Guarrera GM, Favaretti C, Nollo G. Health technology assessment on reprocessing single-use catheters for cardiac electrophysiology: results of a three-years study. Conf Proc IEEE Eng Med Biol Soc. 2007;2007:1758-61.

19 Krüger CM. Processing single-use medical devices for use in surgery - importance, status quo and potential. GMS Krankenhhyg Interdiszip. 2008 Sep;3(3):Doc21.
20 Kwakye G, Pronovost PJ, Makary MA. Commentary: a call to go green in health care by reprocessing medical equipment. Acad Med. 2010 Mar;85(3):398-400.

21 DiConsiglio J. Reprocessing SUDs reduces waste, costs. Mater Manag Health Care. 2008 Sep;17(9):40-2.

22 GAO. GAO report: reprocessed single-use medical devices: FDA oversight has increased, and available information does not indicate that use presents an elevated health risk. Washington (DC): U.S. General Accounting Office; 2008.

23 AMDR. Reduce, reuse, recycle reprocessing medical devices. Washington, DC: Association of Medical Device Reprocessors; 2016 [cited 2018 Mar 19]. Available from: http:// www.hospitalmanagement.net/features/feature80981/

24 Sloan TW. Safety-cost trade-offs in medical device reuse: a Markov decision process model. Health Care Manage Sci. 2007 Feb;10(1): 81-93.

25 US Department of Health and Human Services. Guidance for industry and for FDA staff: enforcement priorities for single-use devices reprocessed by third parties and hospitals. Washington (DC): US Department of Health and Human Services; 2000.

26 União Europeia. Relatório sobre a questão do reprocessamento de dispositivos médicos na União Europeia de acordo com o artigo 12-A da diretiva 93/42/CEE. Bruxelas: União Europeia; 2010 . 